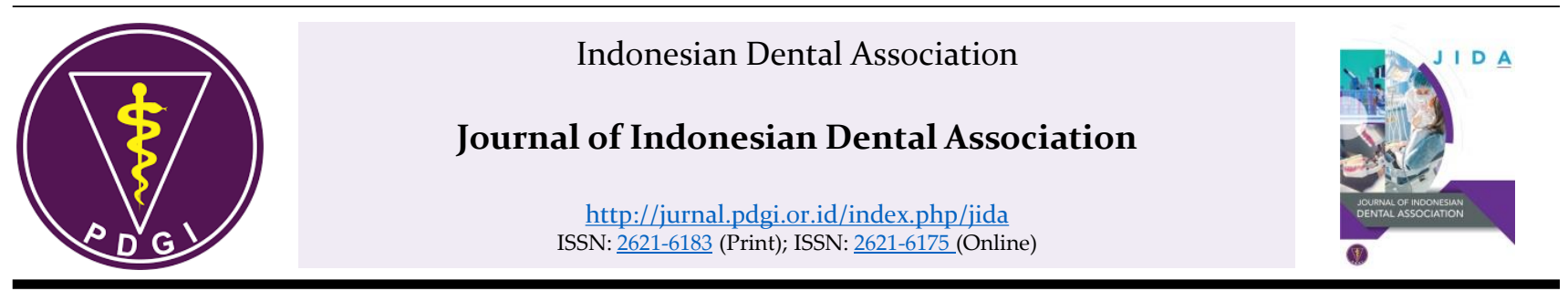

Case Report

\title{
Functional Crown Lengthening: Biological Width Correction
}

\author{
Regia Aristiyanto1§, Diatri Nari Ratih ${ }^{2}$ \\ ${ }^{1}$ Department of Conservative Dentistry, Faculty of Medicine and Health Sciences, Universitas Muhammadiyah Yogyakarta, \\ Indonesia \\ ${ }^{2}$ Department of Conservative Dentistry, Faculty of Dentistry, Universitas Gadjah Mada, Indonesia
}

Received date: November 18, 2019. Accepted date: February 3, 2020. Published date: February 20, 2020.

\section{KEYWORDS}

biological width; functional crown lengthening; root canal retreatment; post crown

\begin{abstract}
Introduction: Functional crown lengthening is one of the most common surgical procedures that facilitating restorative treatment. It was done on teeth with inadequate clinical crowns in the presence of deep and subgingival pathologies. Inadequate clinical crowns defined as tooth with less than $2 \mathrm{~mm}$ cervico-incisal of sound. Case Report: The 32 years old female patient complained on broken restoration on upper left anterior tooth since one week ago. He also complained about upper right anterior tooth that turned brown. The tooth had received root canal treatment with direct composite restoration since 3 years ago, but the restoration on tooth 11 and 21 was broken. The remaining crown on tooth 11 and 21 was less than $2 \mathrm{~mm}$. The periapical radiograph examination showed tooth 11 and 21 was non-hermetic obturation. Functional crown lengthening and root canal treatment was performed on teeth 11 and 21, with porcelain crown restoration and fiber post. Conclusion: Functional crown lengthening result affects the quality of post retreatment restoration. The success of functional crown lengthening is marked by no recurrent gingival hyperplasia after functional crown lengthening.
\end{abstract}




\section{KATA KUNCl}

biological width; crown lengthening fungsional; perawatan ulang saluran akar; pasak mahkota jaket

\begin{abstract}
ABSTRAK
Latar Belakang: Crown lengthening fungsional merupakan salah satu prosedur bedah yang paling umum dilakukan untuk mendukung restorasi. Prosedur crown lengthening fungsional dilakukan pada gigi dengan mahkota klinis yang tidak memadai karena adanya kondisi patologis. Mahkota klinis yang tidak memadai didefinisikan sebagai mahkota gigi dengan panjang serviko-insisal kurang dari $2 \mathrm{~mm}$. Studi Kasus: Pasien pria berumur 32 tahun mengeluhkan tambalan gigi kiri bagian depan atas patah sejak satu minggu yang lalu, serta mengeluhkan tambalan gigi kanan bagian depan atas goyang dan berubah warna menjadi kecoklatan. Gigi telah dilakukan perawatan saluran akar dengan restorasi resin komposit sejak tiga tahun yang lalu, namun restorasi pada gigi 11 dan 21 patah. Terlihat mahkota yang tersisa pada gigi 11 dan 21 kurang dari $2 \mathrm{~mm}$. Pemeriksaan radiograf periapikal menunjukkan bahwa obturasi pada gigi 11 dan 21 tidak hermetis. Dilakukan crown lengthening fungsional dan retreatment pada gigi 11 dan 21, dengan restorasi mahkota jaket porselin dan pasak fiber. Kesimpulan: Hasil perawatan crown lengthening fungsional dapat mempengaruhi kualitas restorasi pasca retreatment. Keberhasilan crown lengthening fungsional ditandai dengan ketiadaan hiperplasi gingiva ulang pasca crown lengthening fungsional.
\end{abstract}

\section{PENDAHULUAN}

Prosedur crown lengthening fungsional merupakan salah satu perawatan yang sering dilakukan untuk mengekspos atau membuka permukaan akar dengan merubah posisi jaringan gusi dan tepi tulang alveolar lebih ke apikal. ${ }^{1}$ Prosedur tersebut bertujuan mempertahankan biological width yang berhubungan dengan kesehatan jaringan periodontal, serta memberikan retensi dan resistensi yang cukup pada restorasi yang akan dilakukan. $^{2}$

Gigi yang membutuhkan retreatment saluran akar pada umumnya memiliki kondisi dengan karies sekunder, fraktur pada mahkota dan atau fraktur pada restorasi yang luas. Tantangan pada retreatment saluran akar berkaitan dengan isolasi, pengambilan bahan pengisi saluran akar dari perawatan sebelumnya, serta restorasi akhir. ${ }^{3}$ Salah satu faktor yang mempengaruhi keberhasilan retreatment saluran akar adalah restorasi akhir. ${ }^{4}$ Restorasi akhir pasca retreatment saluran akar harus mampu mempertahankan dan melindungi struktur gigi yang ada, serta mengembalikan fungsi mastikasi dan estetik. ${ }^{5}$

Gigi dengan kondisi mahkota yang hilang lebih dari setengah membutuhkan pasak saluran akar. Fungsi utama penggunaan pasak adalah retensi dan mempertahankan inti pada gigi yang telah kehilangan struktur koronal secara luas. ${ }^{6}$ Penggunaan mahkota jaket porselen telah digunakan secara luas karena mampu memberikan hasil yang lebih estetis dibanding bahan restorasi lain.

\section{STUDI KASUS}

Pasien wanita berusia 32 tahun mengeluhkan tambalan gigi kiri bagian depan atas patah sejak satu minggu yang lalu, serta mengeluhkan tambalan gigi kanan bagian depan atas goyang dan berubah warna menjadi kecoklatan. Pasien juga mengeluhkan bahwa dua gigi tersebut sakit sejak sekitar enam bulan yang lalu jika digunakan untuk makan. Gigi tersebut pernah dirawat beberapa kali kunjungan dan ditambal dengan bahan tambalan sewarna gigi sekitar tiga tahun yang lalu. Pasien tidak dicurigai memiliki penyakit sistemik dan tidak sedang dalam pengobatan medis.

Pemeriksaan objektif menunjukkan bahwa terdapat tumpatan resin komposit pada seluruh bagian mahkota gigi 11 dengan kondisi goyang dan terdapat perubahan warna, serta tampak sisa struktur gigi sekitar $1 \mathrm{~mm}$. Gigi 21 menyisakan struktur gigi sekitar $0,5 \mathrm{~mm}$ supra gingiva (Gambar 1). Pemeriksaan perkusi positif pada gigi 11 dan 21, sedangkan pemeriksaan palpasi dan mobilitas menunjukkan hasil negatif.

Pemeriksaan radiograf pada gigi 11 dan 21 menunjukkan terdapat area radiopak pada saluran akar, namun terdapat area radiolusen pada 1/3 tengah saluran akar gigi 11. Area radiopak pada saluran akar gigi 21 terlihat kurang mencapai panjang gigi. Pada mahkota gigi 11 terdapat area radiopak pada seluruh permukaan mahkota dan terdapat radiolusen pada bagian 1/3 koronal saluran akar. Diagnosis yang ditegakkan pada gigi 11 dan 21 adalah previously treated disertai periodontitis apikalis simtomatik. Rencana perawatan pada gigi 11 dan 21 adalah crown lengthening, retreatment saluran akar, serta mahkota jaket porselin disertai pasak fiber.

Kunjungan pertama dilakukan pada tanggal 2 Juli 2018. Dilakukan pengukuran untuk prosedur crown lengthening fungsional pada gigi 11 dan 21. Hasil pengukuran menunjukkan kedalaman sulkus hasil probing $0,5 \mathrm{~mm}(\mathrm{~A})$, perkiraan jarak CEJ - alveolar crest berdasarkan radiograf $2 \mathrm{~mm}$ (B), biologic width yang 
preparasi dikonfirmasi dengan foto radiografi (Gambar 8A, 8B dan 8C). Kemudian, dilakukan prosedur etsa dengan asam fosfat $37 \%$ dan bonding (Prime and Bond Universal, Dentsply). Pasak fiber diinsersi dengan semen resin (RelyX U200,3M ESPE) dan dilakukan core build up menggunakan Fiber Reinforced Core Material (Build-it FR, Pentron), kemudian dilakukan pemeriksaan radiograf (Gambar 9). Preparasi mahkota jaket dilakukan, kemudian pencetakan model kerja dengan hydrophilic polysiloxane impression material dan vinyl polysiloxane impression material.

Kunjungan selanjutnya dilakukan sementasi mahkota jaket porselin dengan semen resin (RelyX U200,3M ESPE), kemudian dilakukan pemeriksaan warna, kontur, embrasur, kerapatan tepi, oklusi dan kontak proksimal (Gambar 10). Kontrol satu minggu pasca insersi mahkota jaket pasien tidak ada keluhan, mahkota jaket pada gigi 11 dan 21 dalam keadaan baik, serta tidak terdapat kelainan pada margin gingiva dan jaringan lunak di sekitar gigi 11 dan 21 .

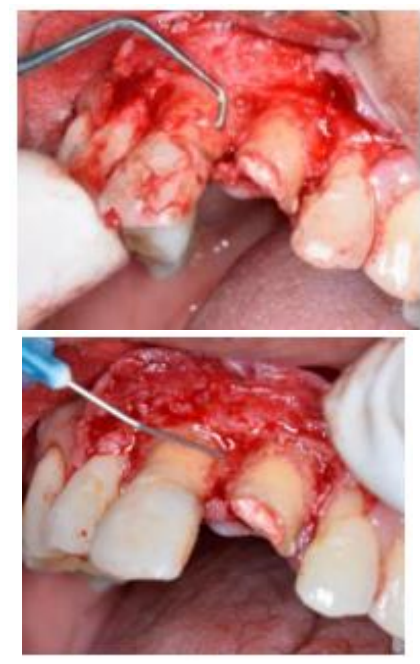

Gambar 4. (A) Pembersihan sisa jaringan lunak menggunakan kuret (B) irigasi dengan larutan salin
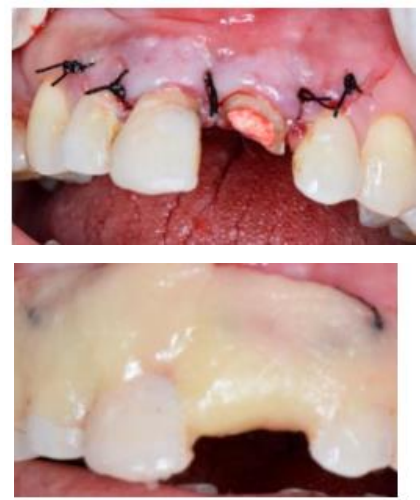

Gambar 5. (A) Penjahitan dengan teknik interupted (B) Aplikasi periodontal pack

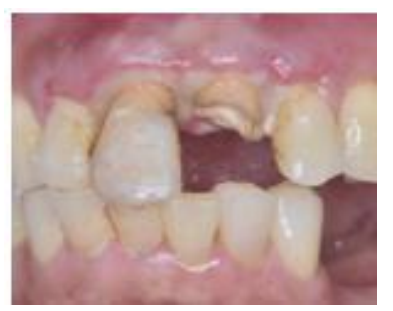

Gambar 6. Foto klinis kontrol satu minggu pasca crown lengthening

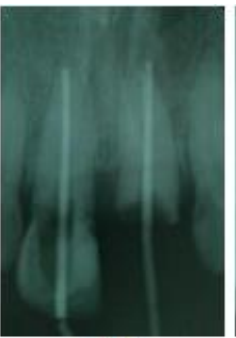

(A)

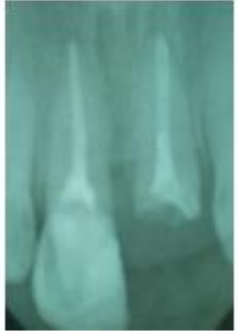

(B)
Gambar 7. (A) Pengepasan master cone terlihat guta perca sesuai dengan panjang kerja (B) Hasil obturasi saluran akar gigi 11 dan 21

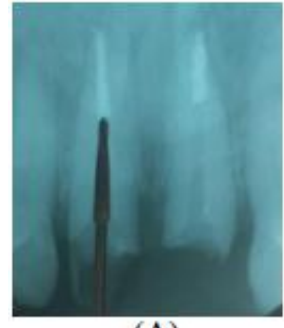

(A)

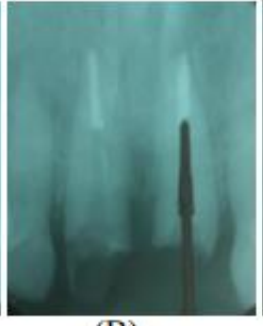

(B)

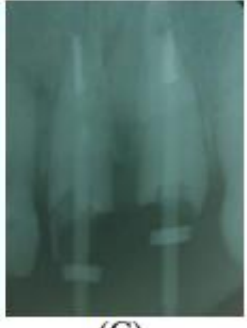

(C)
Gambar 8. Gambaran radiografi pasca pengurangan guta perca dan tracing dengan precission drill (A) pada gigi 11 dan (B) pada gigi 21. (C) Pengepasan pasak gigi 11 dan 21

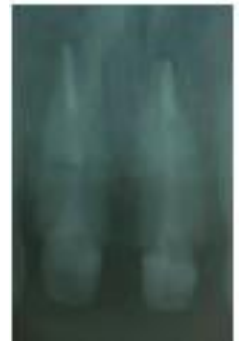

Gambar 9. Radiografi periapikal pasak yang telah disementasi pada gigi 11 dan 21

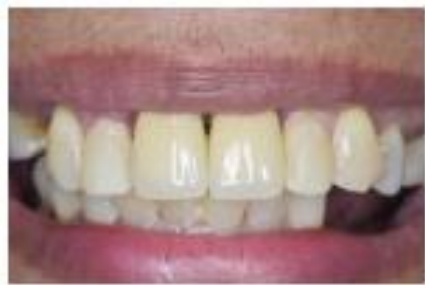

Gambar 10. Foto klinis pasca insersi mahkota jaket 


\section{PEMBAHASAN}

Restorasi pasca perawatan saluran akar atau perawatan ulang saluran akar merupakan salah satu faktor yang menentukan keberhasilan perawatan dan kesehatan jaringan periodontal, terutama pada gigi dengan sisa struktur mahkota dengan kedalaman subgingiva. ${ }^{1,3}$ Tepi restorasi yang terlalu dekat dengan tulang alveolar atau terlalu dalam (subgingiva) dapat menyebabkan inflamasi gingiva, terbentuk poket periodontal dan resorpsi tulang alveolar, karena terdapat perubahan jarak fisiologis antara dasar sulkus gingiva dan puncak tulang alveolar (biological width). ${ }^{7,8}$ Biological width merupakan total epithelial junctional $(0,97 \mathrm{~mm})$ connective tissue attachment $(1,07 \mathrm{~mm})$, sehingga rata-rata dimensi fisiologis biological width adalah 2,04 mm. ${ }^{9}$ Biological width sangat berhubungan dengan kesehatan jaringan periodontal dan restorasi. Perubahan pada biological width dapat menyebabkan respon inflamasi yang mengakibatkan resorpsi tulang alveolar sebagai kompensasi menyediakan ruang untuk perlekatan jaringat ikat, sehingga menyebabkan peningkatan kedalaman poket periodontal. ${ }^{10}$

Struktur mahkota gigi yang pendek merupakan salah satu indikasi crown lengthening fungsional karena dapat mempertahankan biological width. ${ }^{11}$ Selain itu, prosedur crown lengthening fungsional juga dapat memberikan struktur supragingival setinggi $2 \mathrm{~mm}$ atau lebih pada kasus dengan kavitas subgingiva, ${ }^{12}$ sehingga mendapatkan ferrule effect yang meningkatkan resistensi restorasi. ${ }^{13}$ Jovanovski et al menyatakan bahwa gigi yang tidak memiliki ferrule effect lebih rentan mengalami fraktur dibandingkan dengan gigi yang memiliki ferrule effect setinggi $2 \mathrm{~mm} .{ }^{14}$

\section{KESIMPULAN}

Salah satu indikasi crown lengthening adalah indikasi fungsional yang berhubungan dengan perubahan posisi jaringan gingiva dan tepi tulang alveolar ke arah apikal. Pergeseran ke apikal jaringan gingiva dan tulang alveolar berfungsi mempertahankan biological width, sehingga dapat memberikan resistensi yang cukup pada restorasi dan mempertahankan kesehatan jaringan periodontal. Batas tepi gigi pasca crown lengthening fungsional juga memberikan kondisi yang ideal selama perawatan karena memudahkan prosedur isolasi, sehingga mudah didapatkan area kerja yang bersih dan kering.

\section{KONFLIK KEPENTINGAN}

Penulis menyatakan tidak terdapat konflik kepentingan pada penulisan laporan kasus ini.

\section{DAFTAR PUSTAKA}

1. Lanning SK, Waldrop TC, Gunsolley JC, Maynard JG. Surgical crown lengthening: evaluation of the biological width. J Periodontol. 2003;74(4):468-74.

2. Kina JR, Dos Santos PH, Kina EF, Suzuki TY, Dos Santos PL. Periodontal and prosthetic biologic considerations to restore biological width in posterior teeth. J Craniofac Surg. 2011;22(5):1913-6.

3. Gorni FGM, Gagliani MM. The outcome of endodontic retreatment: a 2-years follow-up. J Endod. 2004;30(1):1-4.

4. Chugal NM, Clive JM, Spångberg LS. Endodontic treatment outcome: effect of the permanent restoration. Oral Surg Oral Med Oral Pathol Oral Radiol Endod. 2007;104(4):576-582.

5. Carlos RB, Nainan MT, Pradhan S, Sharma R, Benjamin S, Rose R. Restoration of endodontically treated molars using all ceramic endocrowns. Case Report in Dentistry Hindawi Publishing Corporation. 2013;2013:210763.

6. Bonfante G, Kaizer OB, Pegoraro LF, do Valle AL. Fracture strength of teeth with flared root canals restored with glass fibre posts. Int Dent J. 2007;57:153-160.

7. Gunay H, Seeger A, Tschernitschek H, Geurtsen W. Placement of the preparation line and periodontal health - a prospective 2 year clinical study. Int $\mathbf{J}$ Periodon Rest Dent. 2000;20(2):171-181.

8. Reitemeier B, Hansel K, Walter MH, Kastner C, Toutenburg $\mathrm{H}$. Effect of posterior crown margin placement on gingival health. J Prosthet Dent. 2002;87(2):167-172.

9. Gargiulo AW, Wentz F, Orban B. Dimensions and relations of the dentogingival junction in humans. J Periodontol. 1961;32(3):261-267.

10. Allen EP. Use of mucogingival surgical procedures to enhance esthetics. Dent Clin North Am. 1988;32(2):307-30.

11. Marzadori M, Stefanini M, Sangiorgi M, Mounssif I, Monaco C, Zucchelli G. Crown Lengthening and Restorative Procedures in The Esthetic Zone. Periodontol 2000. 2018;77(1):84-92.

12. Patel RM, Baker P. Functional crown lengthening surgery in the aesthetic zone - periodontic and prosthodontic considerations. Dent Update. 2015;42(1):36-38, 41-42.

13. Mutebi AK, Osman YI. Effect of the ferrule on fracture resistance of teeth restored with prefabricated posts and composite cores. Afr Health Sci. 2004;4(2):131-135.

14. Jovanovski S, Popovski J, Dakskobler A, Marion L, Jevnikar P. The influence of crown ferrule on fracture resistance of endodontically treated maxillary central incisors. Balk J Dent Med. 2017;21:44-49. 